
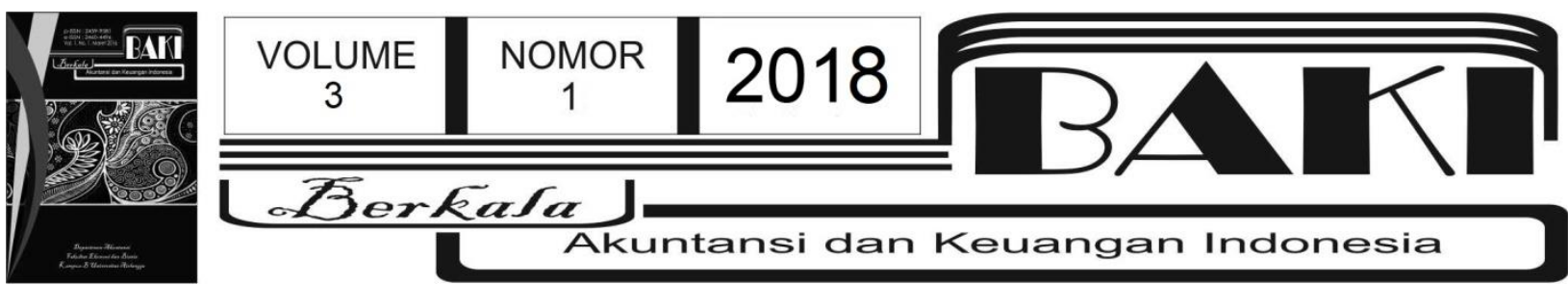

\title{
Analisis Faktor-Faktor yang Memengaruhi Kepatuhan Pajak Bendahara Desa Di Kota Batu
}

\author{
Hendi Subandi ${ }^{1,2}$ \\ Mohamad Irvanuddin Ibnu Fadhil ${ }^{1,3}$ \\ ${ }^{1}$ Universitas Brawijaya \\ ${ }^{2}$ Hendi20@yahoo.com \\ 3Irvan.akunub@gmail.com
}

INFO ARTIKEL

Histori Artikel:

Tanggal Masuk 8 Agustus 2017

Tanggal Diterima 29 Maret 2018

Tersedia Online 31 Maret 2018

Kata Kunci:

bendahara desa; kepatuhan

pajak; kota batu

\begin{abstract}
A B STRAK
Tujuan penelitian ini untuk menganalisis faktor-faktor yang mempengaruhi kepatuhan pajak Bendahara Desa di Kota Batu. Faktor-faktor yang digunakan untuk mengukur kepatuhan pajak adalah pengetahuan pajak, pelayanan pajak dan sanksi pajak. Penelitian ini merupakan penelitian kuantitatif dengan jenis penelitian yang dilakukan adalah survei. Instrumen penelitian yang digunakan adalah menggunakan kuisioner. Responden penelitian adalah seluruh Bendahara Desa di Kota Batu. Seluruh populasi dijadikan sampel, yakni sebesar 38 responden. Alat analisis yang digunakan pada penelitian ini adalah analisis regresi berganda. Hasil penelitian ini menunjukan bahwa terdapat pengaruh positif dan signifikan antara pengetahuan pajak, pelayanan pajak dan sanksi pajak terhadap kepatuhan pajak Bendahara Desa di Kota Batu.
\end{abstract}

\section{Pendahuluan}

Kontribusi pajak bagi pembangunan Indonesia memiliki peran yang signifikan. Terlihat dari kontribusi pajak sebagai sumber penerimaan negara terbesar di Indonesia. Pada APBN 2017, penerimaan negara dari perpajakan mencapai 85,6\% dari total Pendapatan (Kemenkeu 2017). Melihat peran dan kontribusi pajak begitu penting bagi pembangunan Indonesia maka wajar Pemerintah dalam hal ini Direktorat Jendral Pajak (DJP) terus berupaya untuk mengoptimalkan penerimaan tersebut. Berbagai upaya dilakukan mulai dari reformasi sistem administrasi perpajakan dan peningkatan kualitas layanan (Aminah 2014). Namun terjadi 
kontradiksi, menurut Menteri Keuangan, penerimaan pajak dari pelaksanaan APBN tergolong kecil, kurang dari 8\% terhadap total penerimaan pajak pada tahun 2015 dan 2016, hal ini diindikasi akibat penyetoran dan pelaporan pajak terkendala di bendaharawan, yang semestinya pengumpulan pajaknya lebih mudah karena sesama pemerintah (Katadata 2017).

Bendaharawan merupakan Wajib Pajak yang diberi kewenangan sebagai pemotong dan pemungut pajak oleh Undang-Undang Perpajakan, termasuk di dalamnya adalah Bendahara Desa. Pasal 31 Permendagri Nomor 113 Tahun 2014 menyatakan bahwa Bendahara Desa sebagai wajib pungut pajak penghasilan (PPh) dan pajak lainnya, wajib menyetor seluruh penerimaan potongan dan yang dipungutnya ke rekening kas negara sesuai dengan ketentuan peraturan perundang-undangan. Undang-Undang No 6 Tahun 2014 tentang Desa (UU Desa) menjadikan peran bendahara desa, sangat penting karena Undang-Undang Desa dan aturan turunannya mengamanahkan kepada bendahara desa untuk mengatur dan mengelola keuangan desa, tak terkecuali aspek perpajakannya.

Namun, disayangkan kepatuhan bendahara desa dalam melaksanakan kewajiban perpajakannya diindikasikan rendah. Menurut Yon Arsal, Direktur Potensi, Kepatuhan dan Penerimaan Ditjen Pajak menyatakan bahwa meskipun transfer Pemerintah Pusat untuk daerah dan Dana Desa terus meningkat secara signifikan, namun penerimaan pajak dari aktivitas di daerah masih rendah, berada dikisaran 3,6\% (Katadata 2017). Penelitian Sakina (2017) di Sleman juga menegaskan bahwa kepatuhan bendahara desa belum memenuhi syarat kepatuhan formil maupun materil dalam melaksanakan kewajiban perpajakannya.

Penelitian Sakina (2017) merujuk Surat Direktur Ekstensifikasi dan Penilaian Nomor 227/PJ.06/2016 perihal Tindak Lanjut Pendaftaran dan Pengawasan Bendahara Desa yang menunjukkan bahwa pada tahun 2016, dari 74.754 Desa yang ada di Indonesia, Bendahara Desa yang telah memiliki NPWP sebanyak 13.409. sedangkan sisanya, sebanyak 61.345 belum memiliki NPWP. Sementara itu, dari jumlah Bendahara Desa yang telah memiliki NPWP, hanya 9.479 Bendahara Desa yang melakukan penyetoran pajak, sisanya tidak melaksanakan kewajiban perpajakannya. Kondisi ini menggambarkan bahwa kepatuhan wajib pajak Bendahara Desa tergolong masih rendah.

Pada Tahun 2015, Peneliti pernah menjadi salah satu pemateri Bimbingan teknis perpajakan dalam pengelolaan keuangan desa yang di selenggarakan oleh Pemerintah Kota Batu, yang di hadiri oleh seluruh Bendahara Desa dan Kepala Urusan Keuangan Pemerintah Desa di Kota Batu. Hampir 90\% mereka tidak memahami aspek perpajakan yang merupakan kewajiban pajak Pemerintah Desa. Khususnya di PPh 21, PPh 22, PPh 23 dan PPh Final. Hal inilah mendorong peneliti untuk memilih Desa di Kota Batu sebagai wilayah penelitian. Selain adanya beberapa fenomena terkait dana desa yang terjadi di Kota Batu, seperti pada tahun 2015 Pemerintah Kota Batu resmi menolak Dana Desa dari Pemerintah Pusat (Suryamalang.com 2015), pengelolaan Dana Desa tahun 2016 yang diduga bermasalah 
sehingga menyebabkan seluruh Kepala Desa (19 Desa) diperiksa oleh Kejaksaan Kota Batu (Detik.com 2017), serta minimnya kesadaran wajib pajak di Kota Batu untuk membayar pajak, dari 24.000 wajib pajak yang ada di Kota Batu hanya 3.000 wajib pajak yang melaksanakan kewajiban perpajakannya (Suara Indonesia.com 2017).

Minimnya kepatuhan wajib pajak tersebut dapat dipengaruhi oleh beberapa faktor, diantaranya adalah pengetahuan pajak, Pelayanan pajak dan sanksi pajak. Kamil (2015) menyatakan bahwa pengetahuan tentang pajak merupakan penalaran dan makna dari pemahaman tentang peraturan perundang-undangan perpajakan, karena untuk memenuhi kewajiban perpajakannya, masyarakat harus memiliki pengetahuan dan pemahaman tentang peraturan perpajakan, tanpa itu, mungkin mereka tidak akan mau membayar pajak. Sedangkan kualitas pelayanan di kantor pajak dianggap menjadi salah satu indikator penilaian Wajib Pajak Orang Pribadi dalam kesediannya membayar pajak khususnya untuk penerapan self assessment system yang bertujuan untuk meningkatkan kepatuhan membayar pajak (Susmita \& Supadmi 2016). Sementara itu, menurut Honandar (2016), sanksi pajak menyebabkan terpenuhinya kewajiban perpajakan oleh wajib pajak sehingga mengakibatkan meningkatnya kepatuhan wajib pajak.

. Penelitian tentang kepatuhan wajib pajak yang dipengaruhi oleh pengetahuan pajak, pelayanan pajak dan sanksi pajak sudah banyak dilakukan, namun hasilnya menunjukan ketidakkonsistenan, seperti penelitian dari Septariani (2015), Puspa (2012), Susherdianto (2014), Mutia (2014), Honandar (2016) yang menyatakan bahwa faktor-faktor tersebut berpengaruh positif terhadap kepatuhan pajak wajib pajak orang pribadi. Sedangkan penelitian Winerungan (2013), Masruroh (2013) yang menyatakan bahwa faktor-faktor seperti, pelayanan fiskus, sanksi pajak dan pengetahuan pajak tidak berpengaruh terhadap kepatuhan pajak.

Supriyanto (2013) meneliti tentang pengaruh pengetahuan tentang pajak, mutu pelayanan dan kepercayaan masyarakat terhadap kepatuhan membayar PBB di Desa Gandarum Kabupaten Pekalongan, hasil penelitian menunjukkan bahwa pengetahuan tentang pajak, mutu pelayanan dan kepercayaan masyarakat berpengaruh signifikan terhadap kepatuhan membayar PBB di Desa Gandarum. Sementara itu, Sakina (2017) meneliti tentang pelaksanaan kewajiban perpajakan oleh bendahara desa dalam pengelolaan dana desa ditinjau dari asas kepatuhan di Kecamatan Berbah, Sleman. Penelitian ini menggunakan pendekatan kualitatif. Hasil penelitian ini menunjukkan bahwa kewajiban bendahara desa di Kecamatan Berbah, Sleman belum memenuhi kepatuhan materiil dan formil karena banyak hambatan, seperti faktor internal dari pengelolaan dana desa oleh Pemerintah Desa, peran fiskus yang hanya memberitahukan jatuh tempo pembayaran pajak dan pelaporan pajak ke bendahara desa tanpa sosialisasi lebih lanjut dan beberapa faktor lainnya.

Fadhil (2016) meneliti tentang faktor-faktor yang mempengaruhi ketidakpatuhan pajak bendahara desa di Kabupaten Ponorogo dengan menggunakan pendekatan Theory of Planned 
Behavior. Hasil pengujian hipotesis menunjukkan bahwa sikap memiliki pengaruh positif dan tidak signifikan terhadap niat terhadap perilaku tidak patuh Bendahara Desa. Sedangkan norma subjektif memiliki dampak positif dan signifikan terhadap niat terhadap perilaku tidak patuh Bendahara Desa. Juga ditemukan bahwa pengendalian perilaku yang dirasakan mempengaruhi niat terhadap perilaku tidak patuh secara positif dan signifikan, sedangkan kewajiban moral memiliki pengaruh negatif dan tidak signifikan terhadap niat terhadap perilaku tidak patuh. Perceived behavioral control memiliki pengaruh negatif dan tidak signifikan terhadap perilaku ketidakpatuhan pajak. Terakhir, niat untuk perilaku ketidakpatuhan memiliki efek positif dan signifikan terhadap perilaku ketidakpatuhan pajak Bendahara Desa.

Perbedaan penelitian ini dengan penelitian yang telah dilakukan adalah, Pertama, masih terdapat hasil yang tidak konsisten terkait pengaruh pengetahuan pajak, pelayanan pajak dan sanksi pajak terhadap kepatuhan wajib pajak (Septariani (2015); Puspa (2012); Susherdianto (2014); Mutia (2014); Honandar (2016); Winerungan (2013); Masruroh (2013)). Kedua, penelitian sebelumnya lebih banyak meneliti pada wajib pajak orang pribadi (Septariani (2015); Puspa (2012); Susherdianto (2014); Mutia (2014); Honandar (2016); Winerungan (2013); Masruroh (2013)). Ketiga, penelitian tentang kepatuhan bendahara desa yang dilakukan masih berkisar tentang kepatuhan untuk membayar Pajak Bumi dan Bangunan (Supriyanto (2013); Sakina (2017)). Keempat, penelitian yang sudah dilakukan terkait langsung bendahara desa mengunakan pendekatan dan variabel yang berbeda (Fadhil (2016); Sakina (2017)).

Melihat pemaparan di atas, peneliti tertarik untuk melakukan penelitian tentang faktorfaktor apa yang mempengaruhi tingkat kepatuhan pajak bendahara desa di Kota Batu. Faktorfaktor yang digunakan untuk mengukur kepatuhan pajak adalah pengetahuan pajak, pelayanan pajak dan sanksi pajak. Di sisi lain, penelitian tentang kepatuhan pajak bendahara desa masih kurang mendapat perhatian oleh para peneliti. Penelitian ini membatasi hanya pada bendahara desa dan aparatur desa yang melaksanakan kewajiban pajak dan menerima dana desa sesuai UU no 6 Tahun 2014, untuk bendahara yang berada di Kelurahan tidak termasuk dalam lingkup penelitian ini.

\section{Tinjauan Pustaka}

\subsection{Teori Atribusi}

Teori atribusi merupakan teori yang dikemukakan oleh Fritz Heider pada tahun 1958 dan kemudian dikembangkan oleh Harold Kelly pada tahun 1972 (Susherdianto 2014). Pada dasarnya atribusi adalah proses pembentukan kesan, artinya bahwa atribusi merupakan proses dimana seseorang menarik kesimpulan tentang faktor-faktor yang mempengaruhi perilaku orang lain. Teori atribusi menganggap individu sebagai psikolog pemula yang mencoba untuk 
memahami alasan untuk peristiwa yang terjadi dihadapannya. Teori atribusi mencoba untuk menemukan apa yang menyebabkan apa, atau apa yang memotivasi orang untuk melakukan apa pun (Kelley 1973 dalam Kamil 2015). Menurut Susherdianto (2014) teori atribusi sangat relevan untuk menjelaskan hal-hal yang mempengaruhi kepatuhan wajib pajak pada penelitian ini.

Sebagaimana diketahui seseorang dalam menentukan suatu pilihan biasanya orang tersebut menggunakan sikap naluri yang ada didirinya atau mengikuti tren yang berkembang di lingkungan masyarakat. Faktor internal dan eksternal yang dapat mempengaruhi seseorang untuk patuh atau tidak patuh terhadap pajak, misalkan pengaruh faktor internal: pengetahuan akan peraturan perpajakan, dan bagaimana pengenaan sanksi pajak sesuai peraturan perundangan yang berlaku, sedangkan pengaruh faktor eksternal adalah bagaimana fiskus melakukan pelayanan pajak.

\subsection{Kepatuhan Pajak}

Kepatuhan pajak dapat diartikan sebagai kesadaran wajib pajak dalam melaksanakan kewajiban perpajakannya sesuai peraturan perundang-undangan perpajakan secara baik dan benar. Menurut James dan Alley (2002) dalam Saad (2014) kepatuhan pajak mengacu pada kesediaan individu untuk berindak sesuai peraturan perundang-undangan dan administrasi perpajakan tanpa diperlukan penegakan hukum. Pada PMK No 74/PMK.03/2012 disebutkan kriteria wajib pajak tertentu yang disamakan sebagai wajib pajak patuh, yaitu: a) tepat waktu dalam menyampaikan Surat Pemberitahuan; b) tidak mempunyai tunggakan pajak untuk semua jenis pajak; c) laporan keuangan diaudit oleh Akuntan Publik atau lembaga pengawasan keuangan pemerintah dengan pendapat Wajar Tanpa Pengecualian; dan d) tidak pernah dipidana.

\subsection{Pengetahuan Pajak}

Pengetahuan pajak merupakan penalaran dan pemaknaan dari pemahaman atas peraturan perundang-undangan perpajakan (Kamil 2015). Pada sistem perpajakan yang menggunakan self assessment system, pengetahuan pajak merupakan hal yang penting untuk menentukan kewajiban pajak yang akurat (Saad 2014). Menurut Kamil (2015) dengan pengetahuan dan pemahaman tentang peraturan pajak, masyarakat akan berpikiran terbuka, bahwa pajak adalah murni digunakan untuk kebutuhan bangsa dan rakyatnya, dengan pemahaman pajak, tingkat korupsi dan penipuan yang mungkin terjadi dapat diminimalkan, secara bersamaan, tingkat kepatuhan wajib pajak untuk membayar pajak akan meningkat. 


\subsection{Pelayanan Pajak}

Menurut Fuadi dan Mangoting (2013), pelayanan pajak merupakan faktor eksternal yang dapat mempengaruhi tingkat kepatuhan wajib pajak dalam melaksanakan kewajiban perpajakannya. Pemerintah dalam hal ini pihak DJP harus menjalankan fungsi pelayanan dengan baik untuk meningkatkan kepatuhan dari wajib pajak itu sendiri agar penerimaan pajak bisa terus ditingkatkan. Dalam memberikan pelayanan terbaik yang harus dilakukan adalah mengetahui kewajiban dan haknya dalam menjalankan tugas sebagai aparatur pajak (Susherdianto 2014). Direktorat Jenderal Pajak dalam memberikan layanan tentunya harus memenuhi kepuasan pemangku kepentingan yang dilakukan dengan sepenuh hati, transparan, cepat, akurat dan aman serta diperlukan dua perilaku utama untuk mewujudkannya, yaitu: (1) melayani dengan berorientasi pada kepuasan pemangku kepentingan; dan (2) bersikap proaktif dan cepat tanggap (Pajak.go.id 2012).

\subsection{Sanksi Pajak}

Menurut Susherdianto (2014) sanksi pajak adalah suatu hukuman yang diberikan kepada wajib pajak apabila wajib pajak tersebut tidak mematuhi peraturan yang dikeluarkan oleh otoritas pajak. Sanksi pajak dibuat dengan tujuan agar wajib pajak takut melanggar peraturan perpajakan (Kamil 2015). Agar peraturan perpajakan dipatuhi, menurut Honandar (2016) harus ada sanksi perpajakan bagi para pelanggarnya, wajib pajak akan memenuhi kewajiban perpajakannya bila memandang bahwa sanksi perpajakan akan lebih banyak merugikannya. Pelaksanaan sanksi yang dimaksud berupa pemberian denda ataupun sanksi pidana. Pelaksanaan sanksi perpajakan merupakan akibat karena wajib pajak tidak memenuhi kewajiban perpajakannya sebagaimana yang telah diatur dalam undang-undang perpajakan. Pelaksanaan sanksi perpajakan ini menyebabkan terpenuhinya kewajiban perpajakan oleh wajib pajak sehingga mengakibatkan meningkatnya kepatuhan wajib pajak.

\subsection{Bendahara Desa}

Menurut Permendagri No 113 Tahun 2014 Tentang Pengelolaan Keuangan Desa, Bendahara Desa merupakan salah satu unsur PTPKD (Pelaksana Teknis Pengelolaan Keuangan Desa) yang dijabat oleh kepala/staf urusan keuangan dan memiliki tugas untuk membantu Sekretaris Desa. Bendahara Desa memiliki tugas: a) menerima, menyimpan, menyetorkan/membayar, menatausahakan, dan mempertanggungjawabkan penerimaan pendapatan desa dan pengeluaran pendapatan desa dalam rangka pelaksanaan APBDesa; b) Bendahara Desa wajib melakukan pencatatan setiap penerimaan dan pengeluaran serta 
melakukan tutup buku setiap akhir bulan secara tertib; dan c) Bendahara Desa wajib mempertanggungjawabkan uang melalui laporan pertanggungjawaban.

\subsection{Penelitian Terdahulu}

\subsubsection{Pengaruh Pengetahuan Pajak Terhadap Kepatuhan Pajak Bendahara Desa}

Dalam perpajakan, pengetahuan dan pemahaman tentang aturan perpajakan menjadi dasar bagi wajib pajak untuk melaksanakan kewajiban perpajakan. Ketidaktahuan atas suatu aturan perpajakan dapat menyebabkan wajib pajak tidak melaksanakan kewajibannya dengan sebenarnya dan wajib pajak demikian dikatakan sebagai wajib pajak tidak patuh. Kamil (2015) mengungkapkan bahwa pengetahuan wajib pajak mempengaruhi secara signifikan kepatuhan wajib pajak. Penelitian Susherdianto (2014) juga menunjukkan bahwa pengetahuan dan pemahaman perpajakan berpengaruh positif dan signifikan terhadap kepatuhan wajib pajak orang pribadi yang memiliki usaha di Kota Kudus.

Penelitan Saad (2014) menunjukkan bahwa wajib pajak yang memiliki pengetahuan pajak yang tidak memadai dan menganggap bahwa sistem pajak merupakan suatu hal yang kompleks dipandang sebagai faktor terhadap perilaku ketidakpatuhan wajib pajak. Sementara itu, penelitian yang dilakukan oleh Winerungan (2013) menunjukkan bahwa sosialisasi perpajakan tidak memiliki pengaruh terhadap kepatuhan wajib pajak orang pribadi di kota Manado dan Bitung.

Penelitian Palil (2010) menyatakan bahwa pengetahuan Wajib Pajak tentang pajak yang baik akan dapat memperkecil adanya tax evation (mengelak membayar pajak/melanggar aturan). Hasil penelitian Palil menginformasikan kepada para pembuat kebijakan bahwa pengetahuan pajak adalah penting dalam sistem penilaian diri dan dapat mempengaruhi kepatuhan. Pengetahuan pajak memiliki dampak yang siginifikan terhadap kepatuhan pajak. Pengetahuan dan pemahaman tentang aturan perpajakan menjadi dasar bagi wajib pajak untuk melaksanakan kewajiban perpajakan. Pengetahuan wajib pajak (bendahara) terhadap peraturan perpajakan dapat meningkatkan kepatuhan Wajib Pajak dalam melaksanakan kewajibannya. Berdasarkan hal tersebut maka dirumuskan hipotesis sebagai berikut:

\section{H1: Pengetahuan pajak berpengaruh terhadap kepatuhan pajak bendahara desa.}

\subsubsection{Pengaruh Pelayanan Pajak Terhadap Kepatuhan Pajak Bendahara Desa}

Pelayanan pajak merupakan faktor eksternal yang dapat mempengaruhi tingkat kepatuhan wajib pajak dalam melaksanakan kewajiban perpajakannya (Fuadi dan Mangoting 2013). Supriyanto (2013) melakukan penelitian tentang pengaruh mutu pelayanan terhadap 
kepatuhan membayar PBB di Desa Gandarum Kabupaten Pekalongan, hasil penelitian menunjukkan bahwa pengetahuan tentang pajak berpengaruh signifikan terhadap kepatuhan membayar PBB di Desa Gandarum. Honandar (2016), Puspa (2012), Mutia (2014), Pranadata (2014), Septarini (2015) melakukan penelitian terkait pengaruh pelayanan pajak terhadap kepatuhan wajib pajak, hasilnya adalah pelayanan pajak berpengaruh positif dan signifikan terhadap kepatuhan wajib pajak. sementara itu, penelitian Winerungan (2013) menunjukkan sebaliknya yaitu pelayanan fiskus tidak memiliki pengaruh terhadap kepatuhan wajib pajak orang pribadi di kota Manado dan Bitung.

Kepatuhan wajib pajak erat kaitannya dengan upaya peningkatan pelayanan fiskus terhadap wajib pajak. Supadmi (2009) menunjukkan bahwa upaya peningkatan kualitas pelayanan dapat dilakukan dengan cara peningkatan kualitas dan kemampuan teknis pegawai dalam bidang perpajakan, perbaikan dalam insfrastruktur seperti perluasan tempat pelayan terpadu (TPT), penggunaan sistem informasi dan teknologi untuk dapat memberikan kemudahan kepada Wajib Pajak dalam memenuhi kewajiban perpajakannya. Berdasarkan hal tersebut maka dirumuskan hipotesis sebagai berikut:

\section{H2: Pelayanan pajak berpengaruh terhadap kepatuhan pajak bendahara desa.}

\subsubsection{Pengaruh Sanksi Pajak Terhadap Kepatuhan Pajak Bendahara Desa}

Susherdianto (2014) menyatakan bahwa sanksi pajak adalah suatu hukuman yang diberikan kepada wajib pajak apabila wajib pajak tersebut tidak mematuhi peraturan yang dikeluarkan oleh otoritas pajak. Artinya sanksi pajak merupakan alat untuk membuat wajib pajak patuh. Penelitian Kamil (2015), Honandar (2016), Susherdianto (2014), Pranadata (2014), Puspa (2012), Mutia (2014), dan Septarini (2015) menunjukkan bahwa sanksi pajak berpengaruh positif dan signifikan terhadap kepatuhan wajib pajak. Berdasarkan hal tersebut maka dirumuskan hipotesis sebagai berikut:

\section{H3: Sanksi Pajak berpengaruh terhadap tingkat kepatuhan bendahara desa.}

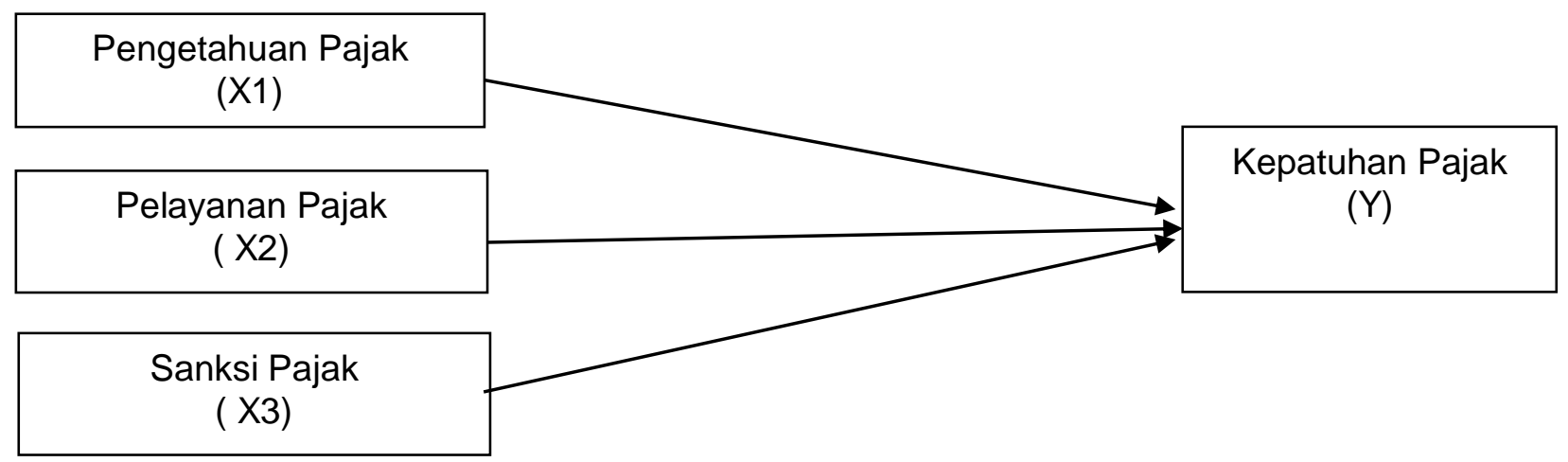




\section{Metodologi Penelitian}

Pendekatan yang digunakan dalam penelitian ini adalah pendekatan kuantitatif karena data yang disajikan berhubungan dengan angka (kuantitatif) dan analisis yang digunakan adalah analisis statistik. Populasi dalam penelitian ini adalah bendahara desa pada instansi pemerintah desa di Kota Batu sebanyak 19 Pemerintah Desa. Seluruh unit populasi dijadikan sampel (total sampling/sensus). Alasannya, dalam penelitian ini, jumlah populasi relatif kecil dan mudah dijangkau. Menurut Sugiyono (2014: 85), teknik penentuan sampel dengan menggunakan semua anggota populasi digunakan sebagai sampel sering dilakukan bila jumlah populasi relatif kecil, kurang dari 30 orang dimana semua anggota populasi dijadikan sampel.

Dengan demikian, karena jumlah Desa di Kota Batu sebanyak 19 Desa dan bendahara desa berjumlah 19 orang. Maka untuk memperkuat hasil penelitian, berdasarkan informasi dari Bendahara Desa, pada praktiknya tugas-tugas kebendaharaan juga seringkali diemban oleh Kepala Urusan Keuangan Pemerintah Desa. Hal tersebut juga sesuai dengan Permendagri No 113 Tahun 2014 Pasal 1 Angka 16 menyebutkan bahwa Bendahara adalah unsur staf sekretariat desa yang membidangi urusan administrasi keuangan untuk menatausahakan keuangan desa. Oleh karena itu, maka penyebaran kuesioner ditambah dengan menyebarkan kepada Kepala Urusan Keuangan di Desa sehingga jumlah sampel bertambah menjadi 38 orang. Alasan pemilihan sampel dalam penelitian ini, karena bendahara desa dan Kepala Urusan Keuangan di Pemerintah Desa melakukan fungsi pengelolaan keuangan desa yang di dalamnya terdapat fungsi sebagai wajib pungut pajak penghasilan (PPh) dan pajak lainnya (Pasal 31 Permendagri Nomor 113 Tahun 2014).

Variabel Dependen dalam penelitian ini adalah kepatuhan pajak bendahara. Instrumen mengukur kepatuhan pajak merujuk kuesioner dari penelitian yang dilakukan Supadmi (2009). Variabel independen pada penelitian ini adalah pengetahuan pajak (Palil 2010), pelayanan pajak (Pranadata 2014), dan sanksi pajak (Pranadata 2014). Instrumen penelitian telah disesuaikan dengan tujuan penelitian ini. Variabel dependen dan variabel independent di ukur dengan menggunakan skala likert 1-5 dengan memberikan pernyataan dalam bentuk kuisioner.

Uji instrumen dilakukan dengan menguji validitas dan reliabilitas dari penelitian. Teknik analisis data yang digunakan adalah analisis statistik deskriptif, uji asumsi klasik yang terdiri dari uji normalitas, uji multikolinearitas dan uji heteroskedastisitas. Selanjutnya dilakukan pengujian hipotesis dengan analisis regresi berganda untuk mengetahui hubungan ketiga variabel secara bersama-sama.

$Y=\alpha+\beta 1 X 1+\beta 2 X 2+\beta 3 X 3+e$

Keterangan : 


$\begin{array}{ll}\mathrm{Y} & : \text { Kepatuhan Pajak } \\ \alpha & : \text { Konstanta } \\ \mathrm{X} 1 & : \text { Variabel pengetahuan pajak } \\ \mathrm{X} 2 & : \text { Variabel pelayanan pajak } \\ \mathrm{X} 3 & : \text { Variabel sanksi pajak }\end{array}$

\section{Analisis dan Pembahasan}

\subsection{Deskripsi Karakteristik Responden}

Penelitian ini menyebarkan kuesioner sebanyak 38 responden. Jumlah tersebut berasal dari 19 desa yang tersebar di Kota Batu. Setiap desa diberikan dua kuisioner, yaitu untuk perangkat yang berfungsi sebagai Bendahara Desa dan Kepala Urusan Keuangan. Pengembalian kembali dari kuisioner tersebut berjumlah $100 \%$. Hal ini dikarenakan peneliti memberikan langsung kuisioner tersebut dan menunggu hasil kuisioner tersebut diselesaikan.

Dari hasil penelitian yang dilakukan didapatkan informasi mengenai responden. Informasi tersebut meliputi jenis kelamin, umur, pendidikan terakhir, dan pengalaman penyuluhan pajak. Dari 38 kuisioner yang ada, jenis kelamin dari responden adalah, 10 orang berkelamin perempuan dan 28 responden berjenis kelamin laki-laki. Umur responden berkisar dari 28 tahun sampai dengan 55 tahun. Dengan rincian sebagai berikut, umur 28 tahun sampai dengan 30 tahun sejumlah 5, umur 31 tahun sampai dengan 40 tahun sejumlah 17, umur 41 tahun sampai sampai 50 tahun sejumlah 14, serta di atas 51 tahun sejumlah 2.

Pendidikan terakhir dari responden adalah sama, yakni seluruh responden berpendidikan terakhir Sekolah Menengah Atas (SMA). Seluruh responden pernah mengikuti pelatihan pajak. Hal ini dikonfirmasi dengan informasi dari kantor pajak Kota Batu yang sering melakukan sosialisasi perpajakan di desa-desa di lingkungan Kota Batu.

\subsection{Uji Validitas dan Reliabilitas}

Dari hasil penelitian dengan menggunakan SPSS didapatkan hasil bahwa semua butir pertanyaan telah valid dengan nilai korelasi lebih tinggi dari pada nilai kritis ( $r$ ), sehingga seluruhnya dapat digunakan untuk penelitian. Pengujian reliabilitas pengetahuan pajak didapatkan nilai Cronbanch's Alpha yang dihasilkan 0,792 >0,60 menunjukkan bahwa konstruk variabel penelitian ini reliabel. Instrumen pelayanan pajak menghasilkan nilai Cronbanch's Alpha yang dihasilkan 0,804 > 0,60 menunjukkan bahwa konstruk variabel penelitian ini reliabel. Instrument sanksi pajak menghasilkan nilai Cronbanch's Alpha yang dihasilkan $0,879>0,60$ menunjukkan bahwa konstruk variabel penelitian ini reliabel. 
Instrument kepatuhan pajak menghasilkan nilai Cronbanch's Alpha yang dihasilkan 0,786 > 0,60 menunjukkan bahwa konstruk variabel penelitian ini reliabel.

\subsection{Uji Hipotesis dan Pembahasan Hasil Penelitian}

Pengujian hipotesis dilakukan dengan metode analisis regresi berganda menggunakan SPSS, didapatkan hasil sebagai berikut: Nilai dari $R$ Square yang diperoleh sebesar 0,533 hal ini menunjukan bahwa pengetahuan pajak, pelayanan pajak dan sanksi pajak berpengaruh sebesar 55,3\% terhadap kepatuhan pajak. Sedangkan sisanya sebesar $44,7 \%$ dipengaruhi oleh variabel lain diluar penelitian ini. Nilai F hitung sebesar 12,954 serta $F$ table sebesar 1,686, hasil ini menunjukan bahwa $F$ hitung lebih besar daripada $F$ table. Hal ini dikatakan bahwa pengetahuan pajak, pelayanan pajak dan sanksi pajak berpengaruh secara bersama-sama secara signifikan terhadap kepatuhan pajak.

\subsubsection{Pengaruh Pengetahuan Pajak Terhadap Kepatuhan Pajak}

Pengujian hipotesis pertama adalah pengetahuan pajak berpengaruh terhadap kepatuhan pajak bendahara desa. Berdasarkan hasil statistik menunjukkan bahwa konstanta sebesar 11,196, hal ini menunjukan besarnya kepatuhan pajak Bendahara Desa akan berpengaruh jika tanpa dipengaruhi variabel pengetahuan pajak $\left(X_{1}\right)$, dengan koefisien regresi sebesar 0,411 maka jika pengetahuan meningkat sebesar 1 satuan, maka kepatuhan meningkat sebesar 0,016.

Dari uji anova didapatkan nilai $F$ hitung sebesar 9,588 dengan tingkat signifikansi $0,04<$ 0,05 , sehingga didapatkan hubungan yang signifikan antara pengetahuan pajak dan kepatuhan pajak. Dengan mengetahui nilai $R$ square sebesar 0,21 , maka dapat dikatakan bahwa variabel pengetahuan pajak berpengaruh sebesar $21 \%$ terhadap kepatuhan pajak. Sedangkan $79 \%$ lainya dipengaruhi variabel lain selain pengetahuan pajak. Dengan t hitung sebesar 3,096 yang nilainya lebih besar dari t table yakni sebesar 0,456 serta nilai signifikansi $0,000<0,05$, maka $\mathrm{H}_{1}$ diterima. yang menunjukan bahwa antara pengetahuan dan kepatuhan pajak berpengaruh secara signifikan terhadap kepatuhan. Artinya semakin baik pengetahuan pajak, maka semakin baik pula kepatuhan pajak dari bendahara desa.

Hasil penelitian ini konsisten dengan penelitian yang dilakukan oleh Supriyanto (2013) yang melakukan penelitian tentang pengaruh pengetahuan tentang pajak terhadap kepatuhan membayar PBB di Desa Gandarum Kabupaten Pekalongan, hasil penelitian menunjukkan bahwa pengetahuan tentang pajak berpengaruh signifikan terhadap kepatuhan membayar PBB di Desa Gandarum. Hasil penelitian ini juga mendukung hasil penelitian dari Kamil (2015), Susherdianto (2014), Saad (2014) yang menyatakan bahwa pengetahuan pajak berpengaruh 
signifikan terhadap kepatuhan pajak. Secara teori, hasil penelitian ini relevan dengan Teori Atribusi, yang menyebutkan bahwa faktor internal dari wajib pajak dapat mempengaruhi seseorang untuk patuh atau tidak patuh terhadap pajak. pengetahuan pajak diketegorikan sebagai faktor internal wajib pajak yang mendorong wajib pajak untuk patuh terhadap kewajiban perpajakannya. Hal ini sejalan dengan pengakuan Bendahara Desa yang menyebutkan bahwa Pemerintah Kota Batu dan KPP Batu sering melakukan sosialisasi terkait dengan pemahaman kewajiban perpajakan, baik secara pemahaman peraturan dan teknis perhitungan pajak PPh 21 dan PPh lainnya.

Namun, hasil penelitian ini berbeda dengan penelitian yang dilakukan oleh Winerungan (2013) dan Pranadata (2014) menunjukkan bahwa sosialisasi perpajakan/ pengetahuan pajak tidak memiliki pengaruh terhadap kepatuhan wajib pajak orang pribadi di kota Manado dan Bitung. Hal ini dimungkinkan karena penelitian yang dilakukan pada lingkup wajib pajak orang pribadi yang sangat luas, sedangkan penelitian ini hanya berfokus pada bendahara desa di kota Batu.

\subsubsection{Pengaruh Pelayanan Pajak Terhadap Kepatuhan Pajak}

Pengujian hipotesis kedua adalah pelayanan pajak berpengaruh terhadap kepatuhan pajak bendahara desa. Berdasarkan hasil statistik menunjukkan konstanta sebesar 11,991. Hal ini menunjukan besarnya kepatuhan pajak Bendahara Desa akan berpengaruh jika tanpa dipengaruhi variabel pelayanan pajak $\left(X_{2}\right)$, dengan koefisien regresi sebesar 0,493 maka jika pelayanan meningkat sebesar 1 satuan, maka kepatuhan meningkat sebesar 0,493.

Dengan mengetahui nilai $R$ square sebesar 0,236, maka dapat dikatakan bahwa variabel pelayanan pajak berpengaruh sebesar $23,6 \%$ terhadap kepatuhan pajak. Sedangkan $76,4 \%$ lainya dipengaruhi variabel lain selain pelayanan pajak. Dari uji anova didapatkan nilai $F$ hitung sebesar 17,426 dengan tingkat signifikansi $0,000<0,05$, sehingga didapatkan hubungan yang signifikan antara pengetahuan pajak dan kepatuhan pajak. Dengan t hitung sebesar 4,174 yang nilainya dibawah t table yakni sebesar 0,325, serta nilai signifikansi $0,000<0,05$, maka $\mathrm{H}_{2}$ diterima. Sehingga didapatkan kesimpulan hubungan antara pelayanan dan kepatuhan pajak berpengatuh secara signifikan. Artinya semakin baik pelayanan, maka semakin baik pula kepatuhan pajak dari bendahara desa.

Hasil penelitian ini mendukung penelitian yang dilakukan oleh Supriyanto (2013), Honandar (2016), Puspa (2012), Mutia (2014), Pranadata (2014), Septarini (2015) yang menyebutkan bahwa pelayanan pajak berpengaruh positif dan signifikan terhadap kepatuhan wajib pajak. Namun hasil penelitian ini berbeda dengan penelitian yang dilakukan oleh Winerungan (2013) yang menunjukkan hasil sebaliknya yaitu pelayanan fiskus tidak memiliki pengaruh terhadap kepatuhan wajib pajak. Secara teori, hasil penelitian ini relevan dengan Teori 
Atribusi, yang menyebutkan bahwa faktor eksternal dari wajib pajak dapat mempengaruhi seseorang untuk patuh atau tidak patuh terhadap pajak. pelayanan pajak diketegorikan sebagai faktor eksternal wajib pajak yang mendorong wajib pajak untuk patuh terhadap kewajiban perpajakannya. Selain itu, peningkatan kualitas pelayanan dari Direktorat Jenderal Pajak melalui Kantor Pelayanan Pajak (KPP) memberikan kemudahan bagi bendahara desa untuk memenuhi kewajiban perpajakannya, seperti adanya penerbitan buku pintar Bendaharawan mahir pajak yang sudah memasukkan aktivitas pengelolaan keuangan desa berikut pengenaan pajaknya. Kemudahan dalam penyetoran dan pelaporan pajak melalui e-billing dan e-filing juga diindikasi menjadi salah satu faktor yang mempengaruhi bendahara desa untuk patuh.

\subsubsection{Pengaruh Sanksi Pajak Terhadap Kepatuhan Pajak}

Pengujian hipotesis ketiga adalah sanksi pajak berpengaruh terhadap kepatuhan pajak bendahara desa. Berdasarkan hasil statistik menunjukkan konstanta sebesar 10,885. Hal ini menunjukan besarnya kepatuhan pajak Bendahara Desa akan berpengaruh jika tanpa dipengaruhi variabel sanksi pajak $\left(X_{3}\right)$, dengan koefisien regresi sebesar 0,472 maka jika sanksi meningkat sebesar 1 satuan, maka kepatuhan meningkat sebesar 0,472. Dengan mengetahui nilai $\mathrm{R}$ square sebesar $34,1 \%$, maka dapat dikatakan bahwa variabel sanksi pajak berpengaruh sebesar 34,1\% terhadap kepatuhan pajak. Sedangkan 65,9\% lainya dipengaruhi variabel lain selain sanksi pajak.

Dari uji anova didapatkan nilai $F$ hitung sebesar 17,426 dengan tingkat signifikansi 0,000 $<0,05$, sehingga didapatkan hubungan yang signifikan antara pengetahuan pajak dan kepatuhan pajak. Dengan $t$ hitung sebesar 2,643 yang nilainya dibawah $t$ table yakni sebesar 0,456 yang menunjukan bahwa antara sanksi dan kepatuhan pajak berpengatuh secara signifikan. Artinya semakin baik pelayanan, maka semakin baik pula kepatuhan pajak dari bendahara desa.

Hasil penelitian ini sejalan dengan penelitian yang dilakukan oleh Kamil (2015), Honandar (2016), Susherdianto (2014), Pranadata (2014), Puspa (2012), Mutia (2014), dan Septarini (2015) yang menyatakan bahwa sanksi pajak berpengaruh positif dan signifikan terhadap kepatuhan wajib pajak. Apabila dikaitkan dengan Teori Atribusi, sanksi pajak ini merupakan faktor internal yang dapat mempengaruhi seseorang untuk patuh atau tidak patuh terhadap kewajiban perpajakannya. Kondisi ini juga dipicu dengan hampir semua lembaga pemeriksa baik dari internal maupun eksternal mengawasi pelaksanaan penggunaan dana desa, seperti Inspektorat, Badan Pemeriksa Keuangan (BPK), Komisi Pemberantasan Korupsi (KPK), Kejaksaan dan lembaga lain terkait. Selain itu, penegakan hukum pajak juga dilakukan dengan seksama oleh KPP, sehingga bendahara desa akan lebih terstimulus untuk patuh daripada nanti terkena sanksi, baik sanksi administrasi maupun sanksi pidana. 


\section{Kesimpulan, Keterbatasan dan Saran}

\subsection{Kesimpulan}

Dari penelitian yang telah dilakukan didapatkan bahwa pengetahuan memiliki pengaruh positif dan signifikan terhadap kepatuhan pajak. Pelayanan pajak berpengaruh positif dan signifikan terhadap kepatuhan pajak. Sanksi pajak berpengaruh positif dan signifikan terhadap kepatuhan pajak. Pengetahuan pajak, pelayanan pajak dan sanksi pajak yang dipersepsikan secara bersama-sama mempunyai pengaruh positif dan signifikan terhadap kepatuhan pajak.

\subsection{Keterbatasan Penelitian}

Keterbatasan dalam penelitian ini adalah peneliti tidak bisa mendapatkan data terkait kepatuhan pajak dari Kantor Pelayanan Pajak (KPP) Pratama Batu sehingga sulit untuk membandingkan antara hasil temuan peneliti dengan data sekunder yang ada. Selain itu, adanya ketakutan dari bendahara desa untuk mengisi kuesioner menjadi kendala, karena dianggap kuesioner yang dibagikan peneliti didapatkan dari petugas pajak dan dianggap peneliti akan menginformasikan kepada petugas pajak. Namun, dengan bekal penjelasan yang baik, akhirnya kuesioner yang dibagikan dapat kembali seluruhnya.

\subsection{Saran}

Saran terkait hasil penelitian ini adalah perlu diberikan pengetahuan khusus tentang pajak agar Bendahara desa dapat memahami hal-hal yang berkenaan dengan peraturan pajak. Pengetahuan bisa melalui sosialisasi/penyuluhan secara gratis bagi para Bendahara baru atau secara berkala mengirimkan pemberitahuan mengenai peraturan perpajakan. Pelayanan pajak oleh fiskus tetap perlu ditingkatkan, karena kepatuhan wajib pajak, khususnya bendahara desa, dalam memenuhi kewajibannya membayar pajak tergantung pada bagaimana petugas pajak memberikan mutu pelayanan yang terbaik kepada wajib pajak. Petugas pajak harus memberikan sanksi kepada bendahara yang tidak patuh dalam memungut/memotong dan menyetorkan pajak.

\section{Daftar Pustaka}

Aminah, S. 2014. Pengaruh Penerapan Sistem Administrasi Perpajakan Modern Terhadap Kepatuhan Wajib Pajak Pada Kantor Pelayanan Pajak Pratama Kota Surakarta. Jurnal UMS. 
Fuadi,Oentara Arabella \& Yenni Mangoting. 2013. Pengaruh Kualitas Pelayanan Petugas Pajak, Sanksi Perpajakan dan Biaya Kepatuhan Pajak Terhadap Kepatuhan Wajib Pajak UMKM.Tax and Accounting Review, Vol 1.No 1.2013

Honandar, Ignatia Rosali. 2016. Pengaruh Sanksi Pajak, Sikap Pelayanan Fiskus, Belanja Pemerintah, dan Nilai Etika Terhadap Tinkat Kepatuhan Wajib Pajak Orang Pribadi. Tesis. Universitas Gadjah Mada.

Kamil, Nurlis Islamiah. 2015. The Effect of Taxpayer Awarness, Knowledge, Tax Penalties and Tax Authorities Services on the Tax Compliance: (Survey on the Individual Taxpayer at Jabodetabek \& Bandung. Research Journal of Finance and Accounting Vol 6. No 2. 2015.

Katadata.co.id. 2017. Setoran Pajak Bendahara Pemerintah Seret, Pengawasan Bakal Diperketat. $\quad 12 \quad$ September $2017 . \quad$ Diakses di https://katadata.co.id/berita/2017/09/12/setoran-pajak-bendahara-pemerintah-seretpengawasan-bakal-diperketat. Pada tanggal 8 Desember 2017.

Kementerian Keuangan Republik Indonesia. 2017, Buku II, Nota Keuangan Beserta Anggaran Pendapatan dan Belanja Negara, Tahun Anggaran 2017. Diakses di https://www.kemenkeu.go.id/Data/nota-keuangan-apbn-2017 pada tanggal 12 April 2017.

Masruroh, Siti. 2013. Pengaruh Kemanfaatan NPWP, Pemahaman Wajib Pajak, Kualitas Pelayanan, dan Sanksi Perpajakan Terhadap Kepatuhan Wajib Pajak (Studi Empiris Pada WP OP di Kabupaten Tegal). Skripsi. Universitas Diponegoro. Semarang.

Mutia, Sri Putri Tita. 2014. Pengaruh Sanksi Perpajakan, Kesadaran Perpajakan, Pelayanan Fiskus, dan Tingkat Pemahaman Terhadap Kepatuhan Wajib Pajak Orang Pribadi: Studi Empiris pada Wajib Pajak Orang Pribadi yang Terdaftar di KPP Pratama Padang. ejournal Akuntansi Vol 2 No 1 Seri D 2014. Universitas Negeri Padang.

Pajak.go.id. 2012. Kenali Layanan Unggulan Perpajakan Bagi Anda. Diakses melalui http://www.pajak.go.id/content/kenali-layanan-unggulan-perpajakan-bagi-anda pada tanggal 3 Agustus 2017.

Palil, Moch. Rizal. 2010. Tax Knowledge and Tax Compliance Determinants In Self Assessment System In Malaysia

Peraturan Menteri Dalam Negeri No 113 tahun 2014 tentang Pengelolaan Keuangan Desa.

Peraturan Menteri Keuangan No 74/PMK.03/2012 tentang Tata Cara Penetapan dan Pencabutan Penetapan Wajib Pajak dengan Kriteria Tertentu dalam Rangka Pengembalian Pendahuluan Kelebihan Pembayaran Pajak

Pranadata Putu. 2014. Pengaruh pemahaman wajib pajak, kualitas pelayanan perpajakan, dan pelaksanaan sanksi pajak terhadap kepatuhan wajib pajak orang pribadi. Jurnal IImiah Mahasiswa. Universitas Brawijaya.

Puspa, Arum. 2012. Pengaruh Kesadaran Wajib Pajak, Pelayanan Fiskus, dan Sanksi Pajak Terhadap Kepatuhan Wajib Pajak Orang Pribadi Yang Melakukan Kegiatan Usaha dan Pekerjaan Bebas: Studi di Wilayah KPP Pratama Cilacap. Skripsi, Universitas Diponegoro, Semarang.

Saad, Natrah. 2014. Tax Knowledge, Tax Complexity, Tax Compliance: tax Payers' View. Procedia-Social and Behavioral Sciences 109 (2014). Elsevier Ltd.

Sakina, Sesty Milla. 2017. Pelaksanaan Kewajiban Perpajakan Oleh Bendahara Desa Dalam Pengelolaan Dana Desa Ditinjau dari Asas Kepatuhan Di Kecamatan Berbah, Sleman. Skripsi. Universitas Gadjah Mada.

Septarini, Dina Fitri. 2015. Pengaruh Pelayanan, Sanksi, dan Kesadaran Wajib Pajak Terhadap Kepatuhan Wajib Pajak Orang Pribadi di KPP Pratama Merauke. Jurnal Ilmu Ekonomi dan Sosial, April, Vol. VI, No. 1. 
Suaraindonesia.com. 2017. Di Kota Batu, 24.000 Wajib Pajak Yang Bayar Hanya 3.000. diakses di http://suaraindonesia-news.com/di-kota-batu-24-000-wajib-pajak-yang-bayarhanya-3-000/ pada tanggal 20 Desember 2017.

Sugiyono. 2014. Metode Penelitian Kuantitatif, Kualitatif, dan Kombinasi (Mixed Methods). Bandung : Alfabeta

Susmita, Putu Rara \& Ni Luh Supatmi. 2016. Pengaruh Kualitas Pelayanan, Sanksi Perpajakan, Biaya Kepatuhan Pajak, dan Penerapan e-filing pada Kepatuhan Wajib Pajak. e-journal Akuntansi. Vol 14 No. 2. Universitas Udayana.

Suryamalang.Com. 2017. Dana Desa di kota Batu Nyantol Karena kendala Ini. 16 Maret 2017. Diakses di http://suryamalang.tribunnews.com/2017/03/16/dana-desa-di-kota-batunyantol-karena-kendala-ini pada tanggal 24 Oktober 2017.

Supadmi, Nih Luh. 2009. Meningkatkan Kepatuhan Pajak Melalui Kualitas Pelayanan. Jurnal Akuntansi dan Bisnis. Vol. 2

Supriyanto. 2013. Pengaruh Pengetahuan Tentang Pajak, Mutu Pelayanan dan kepercayaan masyarakat Terhadap Kepatuhan Membayar Pajak Bumi dan Bangunan (Di Desa Gandarum Kecamatan Kajen Kabupaten Pekalongan Tahun 2013). Journal of Economic Education 2(1) 2013. Universitas Negeri Semarang.

Susherdianto, Rommy. 2014. Analisa Faktor-Faktor yang Mempengaruhi Tingkat Kepatuhan Wajib Pajak (Studi WPOP yang Memiliki Usaha di Kota Kudus). Skripsi. Universitas Diponogoro. Semarang

Undang-Undang Republik Indonesia Nomor 6 Tahun 1983, tentang Ketentuan Umum dan Tata Cara Perpajakan sebagaimana telah diubah menjadi Undang-Undang No 16 tahun 2009.

Undang-Undang Republik Indonesia Nomor 6 Tahun 2014 Tentang Desa

Winerungan, Oktaviane Lidya. 2013. Sosialisasi Perpajakan, Pelayanan Fiskus dan Sanksi Perpajakan Terhadap Kepatuhan WPOP di KPP Manado dan KPP Bitung. Jurnal EMBA, Vol.1, No. 3: 960-970. 